Концепт наполнен отрицательными и положительными реакциями, где отрицательные преобладают и, например, реакция «бедность» входит в приядерную зону.

Анализ реакций возрастных групп выявил, что в сознании людей младшего и среднего возрастов отрицательных реакций меньше по сравнению со старшим поколением.

Реакции граждан России содержат больше негативных оценок, чем реакции респондентов-мигрантов, которые сами являются частью концепта: их реакции чаще всего отличаются или сдержанностью, или эмпатией.

Итак, концепт «мигранты» присутствует в сознании людей разных возрастных и социальных категорий и реализуется многочисленными лексическими репрезентациями.

$$
* * *
$$

1. Бабушкин А. П. Типы концептов в лексико-фразеологической семантике языка, их личностная и национальная специфика. Дис. на соиск. уч. ст. док. фил. наук. Воронеж, 1997.

2. Братерский А. Закат Меркель: Германия уходит из-под контроля, 2018. https://www.gazeta.ru/politics/2018/11/15_a_12060139.shtml (дата обращения 14.02.2020).

3. Колганов Г. Немцы накопили недовольство, 2018. https:/www.kommersant.ru/doc/3726214 (дата обращения 12.01.2020)

4. Краткий словарь когнитивных терминов // под ред. Кубряковой Е. С. - М.: Филол. ф-т МГУ им. М. В. Ломоносова, 1997. - 245 с.

5. Кузнецова М. США закрывают южную границу, 2019. https://www.kommersant.ru/doc/4033084 (дата обращения 12.01.2020).

6. Ожегов С.И., Шведова Н.Ю. Толковый словарь русского языка. М.: Азбуковник, 1997. - 944 с.

7. После рейда полиции возле Сенной площади задержаны десятки мигрантов, 2019. https://www.kommersant.ru/doc/4132389 (дата обращения 14.02.2020).

8. Словарь иностранных слов // под ред. Лехина И.В., Локшиной С.М., Петрова Ф.Н. Шаумяна Л.С. М., 1987. -440 c.

9. Шанский Н. М., Боброва Т. А.. Школьный этимологический словарь русского языка. - М.: Дрофа, 2004.

\title{
Россолова О.А.
}

\section{Специфика основных сценариев коммуникативной ситуации запрета}

Камчатский государственный университет имени Витуса Беринга (Россия, Петропавловск-Камчатский)

doi: $10.18411 /$ spc-26-02-2020-05

idsp: sciencepublic-26-02-2020-05

Запрет является самостоятельным сематическим типом побуждения, потому что обладает особыми семантическими, функциональными, прагматическими характеристиками и имеет свой диапазон языковых средств выражения. Семантика запрета подразумевает побуждение собеседника к прекращению, не совершению или видоизменению действия. Иногда понятия запрет и запрещение разводятся: запрещением называется речевое действие, направленное на побуждение адресата к неосуществлению, прекращению или корректировке действия, названного адресантом. Запрет - это некий объективно существующий смысл; запрещение представляет собой процесс воплощения этого смысла, т.е. акт речи, вербализуемый говорящим в конкретной ситуации общения. Общей функцией запрета является побуждение адресата к неосуществлению, прекращению, видоизменению какого-либо действия. В свою очередь, общая функция дробится на частные функции:

1) регулятивная функция направлена на регулирование, координирование речевого или неречевого поведения адресата: в случае невыполнения запрета к адресату должны быть применены штрафные санкции; 
2) превентивная функция направлена на предотвращение еще не совершившегося речевого или неречевого действия адресата в условиях общения;

3) информативно-констативная функция направлена на информирование адресата о неизвестном ему запрещенном факте или на констатацию запрещенного факта, имеющего место в действительности;

4) коррективная функция направлена на корректировку совершающегося в момент речи или уже совершившегося речевого или неречевого действия адресата в условиях общения.

C учетом частных функций можно выделить следующие типы запрета: регулятивный, превентивный, константивный, коррективный. Примером запретарегулятива могут служить резолюции, постановления и прочие запреты, исходящие от администрации, управляющего органа и т.п., например:

Автомобили не парковать! Выгрузка товара (объявление от администрации магазина) - в данном случае администрация устанавливает нормы неречевого поведения на территории магазина.

И вдруг в мертвой тишине кабинета сам аппарат разразился звоном прямо в лицо финдиректора, и тот вздрогнул и похолодел. «Однако у меня здорово расстроились нервы», - подумал он и поднял трубку. Тотчас же отшатнулся от нее и стал белее бумаги. Тихий, в то же время вкрадчивый и развратный женский голос шепнул в трубку:

\section{- Не звони, Римский, никуда, худо будет}

Трубка тут же опустела. Чувствуя мурашки в спине, финдиректор положил трубку и оглянулся почему-то на окно за своей спиной (М. Булгаков) - превентивная КС запрета: очевидно, что адресант вербализирует запрет с целью несовершения адресатом действия, которое тот намеревался совершить. Также в данном случае РА запрета подкрепляется РА угрозы.

В следующем примере представлен запрет-константив, адресант напоминает о запрещенном факте адресату:

Костюм был погружен в работу и совершенно не замечал той кутерьмы, что царила кругом. Усльхав, что кто-то вошел, костюм откинулся в кресле, и над воротником прозвучал хорошо знакомый бухгалтеру голос Прохора Петровича:

- В чем дело? Ведь на дверях же написано, что я не принимаю (М. Булгаков).

Запрет-корректив подразумевает, что адресант осуществляет запрет с целью корректировки действий адресата, например:

После этого свет погас, и публика затопала ногами. Топала она до тех пор, покуда со сиены не посльшился голос Подколесина:

- Граждане! Не волнуйтесь! Свет потушили нарочно, по ходу действия. Этого требует вещественное оформление.

Публика покорилась... (М. Булгаков).

Выделение разновидностей коммуникативной ситуации (далее - $K C$ ) запрещения позволяет говорить о разных сценариях КС запрещения. частей:

Сценарий регулятивной ситуации запрещения состоит из нескольких составных

1) существует возможность того, что адресат может совершить действие, которое не отвечает общеустановленной норме или правилу;

2) адресант как безличный выразитель нормы, обладающий соответствующим правом, запрещает совершение действия, не отвечающего общеустановленной норме;

3) адресат может соблюсти запрет со стороны адресанта, в таком случае нарушения не произойдет, или может нарушить норму и понести административное или уголовное наказание. 
Однако частновладельческого сектора в городе не оказалось, и братья пообедали в летнем кооперативном саду, где особые плакаты извещали граждан о последнем арбатовском нововведении в области народного питания: ПИВО ОТПУСКАЕТСЯ ТОЛЬКО ЧЛЕНАМ ПРОФСОЮЗА (И. Ильф, Е. Петров) - в данном случае запрет выражается в письменной форме, адресат запрета представляется обобщенным административным лицом, адресат запрета потенциален. Запрет имеет категоричный характер, что подчеркивается с помощью лексемы «только». Адресат не имеет свободы ответных действий: запрет подразумевает, что в случае нарушения запрета адресат подвергнется карательной санкции.

Сценарий превентивной КС запрещения состоит из следующих этапов:

1) адресат имеет намерение совершить поступок, не отвечающий намерениям адресанта или нарушающий интересы каждой из сторон или обеих сторон;

2) адресант получает информацию о намерении адресата;

3) адресант запрещает адресату совершать данное действие, предупреждая или не предупреждая о возможных отрицательных последствиях;

4) адресат может последовать запрету и сохранить равновесие в отношениях с адресантом, может подчиниться воле адресанта, если тот согласиться соблюсти выдвинутые адресатом условия, может отказаться от соблюдения запрета, вследствие чего наступят негативные последствия для одной из сторон или для обеих сторон. В случае несоблюдения адресатом запрета его действия могут подвергаться критике, что приводит к нарушению или размыканию речевого контакта, или же действия адресата могут игнорироваться адресантом, что также приводит к размыканию контакта.

Сержант Хиггинс с пистолетом в руке упирался дубинкой в грудь одного из рабочих и бормотал:

\section{поспокойней...}

- Никаких незаконных действий, ребята, поспокойней, ребята,

Сквозь толпу протолкался облепленный пластырями Джошуа.

- Мы не хотим ни с кем ссориться, мистер инспектор, - прохрипел он, уставясь на Юрковского злобнылм глазом. - Но мы не допустим здесь этих ваших штучек (А. Стругачкий, Б. Стругаџкий) - цель РА запрета - предотвратить нежелательные действия адресата. Адресантом является представитель порядка, преобладание его социально-ролевого статуса подчеркивается тем, что у него есть пистолет, дубинка, он имеет право выражаться запрет. Адресатом запрета является группа рабочих, нарушающих трудовую дисциплину и порядок. Исход КС неуспешен, т.к. характер ответных действий адресата выражает несогласие с запретом: «прохрипел», «уставясь злобным глазом». В ответ адресат выдвигает ультиматум представителям порядка: «мы не допустим здесь этих ваших штучек».

Сценарий информативно-констативной коммуникативной ситуации запрещения состоит из следующих компонентов:

1) адресат намеревается совершить или уже совершил действие, которое не отвечает общественной или ситуативной норме;

2) адресант получает информацию о намерении адресата совершить действие или о совершении действия;

3) адресант сообщает адресату о ненормативности его намерения или действия, если адресат не обладает информацией об этом, или о невозможности нарушения норм. Адресант может дать отрицательную оценку деятельности адресата и предупредить о негативных последствиях; 
4) адресат может прислушаться к мнению адресанта и последовать запрету или может нарушить запрет и понести наказание за нарушение нормы, подвергнуться критике и порицанию.

- Почему бы не ограбить? - сказал он менее настойчиво.

- Разве так трудно? Корейко вечером идет по улище. Темно. Я подхожу с левой руки. Вы подходите справа. Я толкаю его в левый бок, вы толкаете в правый. ...Тут я даю ему по морд...

- В том-то и дело, что бить нельзя, - лицемерно вздохнул Паниковский. Бендер не позволяет.

- Да я сам знаю... В общем, я хватаю его за руки, а вы смотрите, нет ли в карманах чего лишнего. Он, как водится, кричит «милиция», и тут я его... Ax mbl, черт возьми, нельзя бить. В общем, мы уходим домой. Ну, как план? (И. Ильф, Е. Петров) цель запрета - напомнить о существующем запрете. Адресант запрета, узнав о намерениях адресата, напоминает ему о ненормативности планируемых действий. Исход КС успешен, т.к. адресат признает запрет и не собирается его нарушать.

Сценарий коррективной коммуникативной ситуации запрещения включает в себя следующие этапы:

1) адресат намеревается совершить или совершает определенное действие;

2) адресант получает информацию о намерении адресата или о совершении адресатом определенного действия, нарушающего интересы адресанта или не соответствующего ситуации общения;

3) адресант запрещает совершение действия или предлагает видоизменить действие;

4) адресат может согласиться с адресантом и сохранить коммуникативную гармонию, может выдвинуть свои условия и при их соблюдении согласиться с адресантом, может нарушить запрет, что приведет к размыканию речевого взаимодействия.

Ипполит Матвеевич начал кое-что соображать.

- Отпустите стул! - завизжал вдруг Авессалом Владимирович. - Сльишите?

Bbl! Бюрократ! Ипполит Матвеевич покорно отпустил стул и пролепетал:

- Простите, недоразумение, служба такая (И. Ильф, Е. Петров).

В данном случае цель РА запрета - прекратить невербальные действия адресата, нарушающие интересы говорящего. Исход КС успешный, т.к. адресат запрета покоряется воле говорящего и выполняет каузируемое действие.

PA запрета обладает побудительной целью, функция запрета указывает на то, к чему конкретно побуждает запрет. В соответствии с этим строятся сценарии КС запрета, исход которых зависит от поведения адресата. КС включает в себя внеязыковую и языковую действительность, то есть содержит объективно существующую реальность и ее отражение во внутреннем мире коммуникантов. В связи с этим КС может характеризоваться по разным признакам: по составу коммуникантов, по обусловленности запрета, по отношению статусов коммуникантов, по характеру ответных действий адресата и исходу ситуации и т.д. В КС находят отражение индивидуальные характеристики коммуникантов, они влияют на ход коммуникации. Исход коммуникации является признаком ее успешности или неуспешности и зависит от личностных характеристик коммуникантов, от условий общения, от реализуемых функций, мотива говорящего и типа адресата, от сценария KC. 